\title{
Behaviour Pattern of Dividend and Earnings: A Study on Selected PSUs in India
}

\author{
${ }^{1}$ Dr. Alpa A. Thaker, ${ }^{2}$ Dr. Mahendra H. Maisuria, ${ }^{3}$ Dr. Prashant T. Jariwala \\ ${ }^{1}$ Assistant Professor, ${ }^{2,3}$ Associate Professor, City C.U. Shah Commerce College Laldarwaja, \\ Ahmedabad, India. \\ 1'thaker_alpa@yahoo.com, ${ }^{2}$ mahendramaisuriya@gmail.com, ${ }^{3}$ pjari66@gmail.com
}

\begin{abstract}
India is the world's third largest energy consumer globally. The oil and gas sector is among eight core industries in India. It plays a major role in influencing decision making for all the other important sections of economy. This paper attempts to identify the dividend and earning patterns across the five selected companies from the oil and power sector in India. Through this paper researchers are also able to find out what kind of policy companies are following whether its dividends are paid according to its earnings or not. The study is conducted by collecting secondary sources from selected PSUs for five financial years. The conclusion has drawn from the study that among the five selected companies the BPCL has provided a good dividend pay-out ratio over the study period. Through the analysis it is found that companies have followed different dividend policies like constant, regular or irregular.
\end{abstract}

KEYWORDS: Dividend, Earning, Public Sector Units

\section{INTRODUCTION}

The oil and gas industry is among the 8 core industries in India. It plays a significant role in influencing decision making for all the other important sections of the economy. India's economic growth is closely related to energy demand so the need of this sector is expected to grow more and more. It makes the sector quite conductive for investment. India is the third largest energy consumer globally. Demand is expected to increase to 1516 million tonnes of oil by $2035^{1}$.

Dividend is the portion of the net profit which company distributes among its shareholders according to resolution passed in Board of Directors meetings. It may be a lump sum amount or at a fixed percentage on a share. It is the most important decision for the top management to decide how much profit should be transferred to the reserve fund to meet future needs or how much should be distributed among equity shareholders.

\section{LITERATURE REVIEW}

- Dr. Jitendra Kumar (2019) looked at the behaviour pattern of dividend pay-out of 10 blue chip companies in India during 2011-12 to 2015-16. He measured their vital measures DPS, EPS and DPR. In his research he concluded that among 10 companies, Coal India has provided a good dividend pay-out over study period.

- Geetanjali Pinto and Shailesh Rastogi (2019) studied sectoral analysis of factors influencing dividend policy. Longitudinal study used the data of companies listed

${ }^{1}$ www.ibef.org on NSE for 12 years from 2006-2017. They found that the size, profitability and interest coverage ratio have a significant positive relation to dividend policy. Business risk and debt revealed a negative relation with dividend policy. They also found that Indian companies follow a stable dividend policy.

- Dr. Nandan Velankar, Ankita Chandani \& Amanpreet Kaur (2017) examined the impact of EPS and DPS on stock price. They have taken 12 public sector banks for the study period 2006-07 to 2014-15. By using the Dickey Fuller test, they disclosed that there was a significant impact of EPS and DPS on stock price. They revealed that DPS and EPS can be noted as an integral factor bearing an impact on stock prices for further study. They also found that DPS has a strong relationship with stock price.

- Hirindu Kawshala and Kushani (2017) checked the effect of dividend policy on corporate profitability. They conducted a sectional survey and exploited the sample frame of the Beverages, Food \& Tobacco industry in Sri Lanka. Ten companies have taken as samples for the study period of 2012 to 2015. Researchers measured DPR for dividend policy and ROE for profitability. Their study concluded that there is a positive significant relationship between dividend policy and the profitability in selected industries in Sri Lanka.

- Dr. K.P. Balakrishnan (2016) has examined the impact of EPS, DPS, and earnings ratio on behaviour of share price movements of five companies from the Pharma sector listed on NSE during 2010-15. He has taken EPS, DPS, and P/E ratio as independent variables and 
MPS as dependent variables. The researcher analysed the strength of association of variables on share price. The analysis showed that share prices of companies were not affected by the selected independent variable, only few companies were affected.

- Joshua Aroni, Prof. G. Namusonge and Dr. Maurice Sakwa (2014) studied the influence of Dividend Payout on investment in shares. For the study researchers collected primary data from 311 respondents participating at Nairobi Securities Exchange in March 2013. They concluded that policy makers committed to enhance securities market activity should purposely structure strategies aimed to increase profitability. Their study findings were different to MM the dividend irrelevance theory. They also found that dividend payout did not have a behaviour influence on investment decisions.

- Al-Ajmi, Jasim, Hameeda Abo Husain (2011) studied that current dividends affected by their past and future prospectus. Dividends less associated with net earnings pay-out ratio have significant negative correlation with company's leverage. Dividends have a significant impact on stock prices and firms have follow flexible dividend policies when profit declines. They found that lagged dividend payment, profitability, cash flow were determinants of dividend payments.

\section{OBJECTIVES OF THE STUDY}

In the present research an attempt has been made to study the pattern of dividend policy and earnings by selected PSUs in India. More precisely the following are the objectives of the study:-

- To study the similarity of selected variables across the PSUS.

- To analyse the behaviour pattern of dividend policy of selected PSUs.

- To find a relation between earnings and dividend of selected PSUs.

\section{RESEARCH HYPOTHESIS}

The study has undertaken to test the following hypothesis.

There is no significant difference in behaviour pattern of dividend and earnings among selected companies.

\section{RESEARCH METHODOLOGY}

\section{Research Design}

Here researchers have used quantitative research work by collecting and analysing data obtained from various sources. It has involved the use of mathematical and statistical tools to derive results of the study.

\section{Selection of the Sample}

Convenience sampling method has been used for selection of samples. Five Maharatna companies (As on Oct. 2019) of PSUs have been selected from the Oil and Power sector listed on BSE India. These companies are,
- $\quad$ Bharat Petroleum Corporation Limited (BPCL)

- Gas Authority of India Limited (GAIL)

- $\quad$ Oil and Natural Gas Corporation Limited (ONGC)

- Indian Oil Corporation Limited (IOCL)

- Hindustan Petroleum Corporation Limited (HPCL)

\section{Selection of Variables:}

\section{Earnings per Share}

It is the portion of companies' total earnings that is allocated to ordinary shareholders. It is an important financial measure which indicates the profitability of a company.

\section{Dividend per share}

It is a share of a declared dividend issued by a company for its ordinary shareholders. It is derived using the dividend paid in the most recent quarter which is used to calculate the dividend yield.

\section{Dividend Pay-out Ratio}

The dividend pay-out ratio is the ratio of the total amount of dividends paid out to shareholders relative to the net income of the company.

\section{Study Period}

Five consecutive financial years from 2014-15 to 2018-19 have been taken as study periods.

\section{Data Collection}

Secondary data have been used to collect data for the research which is primarily compiled from financial statements of PSUs. Websites like moneycontrol.com and others, articles of journals are also used.

\section{Limitation of the Study}

- Researchers have taken data for five years only.

- The data have been analysed for five selected PSUs from oil and power sector.

\section{Analysis of Data}

For analysing secondary data, mathematical tools like average, percentage and statistical techniques like measure of central tendency, dispersion, Parametric $\mathrm{T}$ test and one way ANOVA have been used.

\section{FINDINGS AND DISCUSSION}

Table 1: Showing the EPS (In ₹.) of Five PSUS in India

\begin{tabular}{|l|l|l|l|l|l|}
\hline YEAR & ONGC & IOCL & HPCL & BPCL & GAIL \\
\hline $2014-15$ & 20.73 & 21.72 & 80.62 & 70.32 & 23.96 \\
\hline $2015-16$ & 18.86 & 47.44 & 113.94 & 102.78 & 18.12 \\
\hline $2016-17$ & 13.95 & 40.31 & 61.09 & 61.31 & 20.71 \\
\hline $2017-18$ & 15.54 & 22.52 & 41.71 & 40.55 & 20.48 \\
\hline $2018-19$ & 21.24 & 18.4 & 39.55 & 36.26 & 26.72 \\
\hline Mean & 18.06 & 30.08 & 67.38 & 62.24 & 22 \\
\hline C.V & 17.75 & 43.01 & 45.84 & 42.92 & 15.27 \\
\hline Skewness & -0.43 & 0.71 & 0.91 & 0.86 & 0.54 \\
\hline SUM & 90.32 & 150.39 & 336.91 & 311.22 & 109.99 \\
\hline Source: - & Ca & & & \\
\hline
\end{tabular}

Source: - Calculated by Author 
Table 1 is showing EPS of the selected five PSUs in India. Total highest earning per share during the study period was reached by HPCL (₹ 336.91) and total lowest earning EPS in five years was paid by ONGC (₹ 90.32). Average highest EPS was paid by HPCL followed by BPCL (₹ 62.24) and lowest average of EPS was paid by ONGC ( $₹$ 18.06). Coefficient of variation which also shows relative standard deviation of EPS was highest for HPCL with ₹45.84 and the lowest C.V was shown in GAIL (₹ 15.27). This means that actual EPS of HPCL was widely varied from its average EPS during study period and the variation was very low for actual EPS and average EPS of GAIL during the study period. Skewness means asymmetry in a symmetrical bell curve in a set of any data. Highest skewness was shown by HPCL (0.91) followed by BPCL (0.86), IOCL with 0.71 then GAIL with (0.54) and lowest for ONGC with -0.43 . Investors mostly use standard deviation to predict future earnings but for accurate measure skewness is used to predict risk for future performance. More skewed data will show them a less accurate financial model of the companies.

\section{Table 2: Showing the DPS (in ₹) of Five PSUs in India}

\begin{tabular}{|l|l|l|l|l|l|}
\hline YEAR & ONGC & IOCL & HPCL & BPCL & GAIL \\
\hline $2014-15$ & 9.5 & 6.6 & 24.5 & 22.5 & 6 \\
\hline $2015-16$ & 8.5 & 14 & 34.5 & 31 & 5.5 \\
\hline $2016-17$ & 7.55 & 19 & 30 & 32.5 & 11.2 \\
\hline $2017-18$ & 6.6 & 21 & 17 & 21 & 9.09 \\
\hline $2018-19$ & 7 & 9.25 & 15.9 & 19 & 7.14 \\
\hline Mean & 7.83 & 13.97 & 24.38 & 25.2 & 7.786 \\
\hline C.V & 15 & 44.03 & 33.09 & 24.32 & 30.25 \\
\hline Skewness & 0.6438 & -0.055 & 0.16 & 0.455 & 0.768 \\
\hline SUM & 39.15 & 69.85 & 121.9 & 126 & 38.93 \\
\hline
\end{tabular}

Source: - Calculated by Author

Table 2 indicates Dividend per Share of the five selected PSUs during the study period. It shows the highest dividend was paid by BPCL (₹ 126) among selected companies. Total lowest dividend was paid by GAIL ( $₹$ 38.93). It also indicates DPS mean value of BPCL is highest ( $₹ 25.2$ ) which is highest across the selected PSUs during study period followed by HPCL (₹ 24.38), IOCL (₹ 13.97) and least average DPS paid by GAIL (₹ 7.786).The value of C.V. of IOCL was 44.03 which was the highest and C.V of DPS was lowest for ONGC. The actual DPS was widely differ from average DPS in case of IOCL and low for ONGC. Skewness of DPS was 0.768 for GAIL which is highest in five years and lowest for IOCL with -0.055 . Except IOCL all companies' skewness values were greater than 0 which indicated a positive skewed tail.
Table 3: Showing the DPR (in \%) of Five PSUS in India

\begin{tabular}{|c|c|c|c|c|c|}
\hline YEAR & ONGC & IOCL & HPCL & BPCL & GAIL \\
\hline $2014-15$ & 45.83 & 30.38 & 30.35 & 31.99 & 25.04 \\
\hline $2015-16$ & 30.47 & 25.5 & 30.24 & 30.16 & 30.34 \\
\hline $2016-17$ & 53.17 & 55.19 & 56.01 & 70.15 & 41.64 \\
\hline $2017-18$ & 38.92 & 44.4 & 36.51 & 36.16 & 37.9 \\
\hline $2018-19$ & 35.91 & 57.24 & 22.74 & 49.64 & 28.77 \\
\hline Mean & 40.86 & 42.54 & 35.17 & 43.62 & 32.74 \\
\hline C.V & 21.63 & 33.61 & 35.91 & 38.23 & 20.87 \\
\hline Skewness & 0.45 & -0.22 & 1.43 & 1.3 & 0.41 \\
\hline SUM & 204.3 & 212.71 & 175.85 & 218.1 & 163.69 \\
\hline & \multicolumn{3}{|c}{ Source: - Calculated by Author } \\
\hline
\end{tabular}

Table 3 is showing dividend pay-out ratio (DPR) of selected units of power and gas sector in India. Total paid ratio of BPCL was the highest ( $₹ 218.1$ ), followed by IOCL then ONGC and least paid by GAIL. The highest mean dps was paid by BPCL (₹ 43.62) and lowest mean dps was paid by GAIL ( $₹ 32.74$ ). Coefficient of Variance is highest in BPCL (38.23) and lowest variance is shown by GAIL (20.87). Positive skewness was shown by ONGC (0.45), HPCL (1.43), BPCL (1.3), and GAIL (0.41). Lowest skewness was shown by IOCL $(-0.22)$.

\section{Table 4: One Way Analysis of Variance}

\begin{tabular}{|c|c|c|c|c|c|c|c|}
\hline $\begin{array}{l}\text { Varia } \\
\text { bles }\end{array}$ & Measures & $\begin{array}{l}\text { Sum of } \\
\text { Squares }\end{array}$ & $\begin{array}{l}\text { D } \\
\text { F }\end{array}$ & $\begin{array}{l}\text { Mean } \\
\text { Squares }\end{array}$ & $\begin{array}{l}\mathrm{F} \\
\text { Calcul } \\
\text { ate }\end{array}$ & $\begin{array}{l}\text { F } \\
\text { Critic } \\
\text { al }\end{array}$ & Action \\
\hline \multirow[t]{3}{*}{ EPS } & $\begin{array}{l}\text { Between } \\
\text { Groups }\end{array}$ & 10741.32 & 4 & 2685.33 & \multirow[t]{3}{*}{7.23} & \multirow[t]{3}{*}{2.87} & \multirow[t]{3}{*}{$\begin{array}{l}\mathrm{H} 0=\mathrm{Re} \\
\text { ject }\end{array}$} \\
\hline & $\begin{array}{l}\text { Within } \\
\text { Groups }\end{array}$ & 7426.97 & $\begin{array}{l}2 \\
0\end{array}$ & 371.35 & & & \\
\hline & Total & 18168.3 & $\begin{array}{l}2 \\
4\end{array}$ & & & & \\
\hline \multirow[t]{3}{*}{ DPS } & $\begin{array}{l}\text { Between } \\
\text { Groups }\end{array}$ & $\begin{array}{l}5891465 . \\
324\end{array}$ & 4 & $\begin{array}{l}366.331 \\
1\end{array}$ & \multirow[t]{3}{*}{12.42} & \multirow[t]{3}{*}{2.87} & \multirow[t]{3}{*}{$\begin{array}{l}\mathrm{H} 0=\mathrm{Re} \\
\text { ject }\end{array}$} \\
\hline & $\begin{array}{l}\text { Within } \\
\text { Groups }\end{array}$ & 0.71272 & $\begin{array}{l}2 \\
0\end{array}$ & $\begin{array}{l}29.4856 \\
4\end{array}$ & & & \\
\hline & Total & $\begin{array}{l}2055.037 \\
144\end{array}$ & $\begin{array}{l}2 \\
4\end{array}$ & & & & \\
\hline \multirow[t]{3}{*}{ DPR } & $\begin{array}{l}\text { Between } \\
\text { Groups }\end{array}$ & 456.15 & 4 & 114.04 & \multirow[t]{3}{*}{0.74} & \multirow[t]{3}{*}{2.87} & \multirow[t]{3}{*}{$\begin{array}{l}\mathrm{H} 0=\mathrm{Ac} \\
\text { cept }\end{array}$} \\
\hline & $\begin{array}{l}\text { Within } \\
\text { Groups }\end{array}$ & 3067.21 & $\begin{array}{l}2 \\
0\end{array}$ & 153.36 & & & \\
\hline & Total & 3523.36 & $\begin{array}{l}2 \\
4\end{array}$ & & & & \\
\hline
\end{tabular}

Source: - Secondary Data Analysis

Table 4 has reported the analysis of variance with ANOVA which indicates whether the model significantly differs or not. ANOVA test is applied for all three variables of all selected PSUs. Here calculated Value of F for EPS is 7.23 which is more than its critical value of $F$. Thus null hypothesis is rejected that there is a significant difference in EPS among all selected PSUs during study period. Similar result apparent for DPS. In case of DPS calculated value of $F$ is 12.42 which is more than its critical value 2.87 . Thus the null hypothesis is rejected. Calculated the value of $F$ for DPR is 0.74 which is less than its critical value 2.97 . So a null hypothesis is accepted and an alternative hypothesis is 
rejected. We can say that there is no significant difference in dividend pay-out ratio among selected companies during the study period. It means selected companies follow the same pattern of pay out.

Table 5: EPS Paired Samples Test

\begin{tabular}{|c|c|c|c|c|c|}
\hline COMPANY & ONGC & IOCL & HPCL & BPCL & GAIL \\
\hline \multirow[t]{2}{*}{ ONGC } & & -1.845 & -3.622 & -3.71 & -3.029 \\
\hline & & (0.139) & $(0.022)$ & $(0.021)$ & $(0.039)$ \\
\hline \multirow[t]{2}{*}{ IOCL } & & & -3.572 & -3.935 & 1.145 \\
\hline & & & $(0.022)$ & $(0.017)$ & $(0.316)$ \\
\hline \multirow[t]{2}{*}{ HPCL } & & & & -0.548 & 3.081 \\
\hline & & & & (0.613) & $(0.031)$ \\
\hline \multirow[t]{2}{*}{ BPCL } & & & & & 3.105 \\
\hline & & & & & $(0.036)$ \\
\hline \multicolumn{6}{|l|}{ GAIL } \\
\hline & & & & & \\
\hline
\end{tabular}

Source: - Secondary Data Analysis

Table no. 5 shows the results of paired t-test at 5\% significance level and the result indicates that the mean value of EPS of ONGC is not significantly differ from IOCL, BPCL, HPCL and GAIL. The mean value of IOCL is significantly different from GAIL followed by HPCL and GAIL, BPCL and GAIL where the significant value is less than the calculated value so the null hypothesis is rejected and the alternative hypothesis is accepted.

\section{Table 6: DPS Paired Samples Test}

\begin{tabular}{|l|l|l|l|l|l|}
\hline COMPANY & ONGC & \multicolumn{1}{|c|}{ IOCL } & HPCL & BPCL & GAIL \\
\hline ONGC & & -1.973 & -4.958 & -6.553 & 0.031 \\
\hline IOCL & $(0.120)$ & $(0.008)$ & $(0.003)$ & $(0.977)$ \\
\hline HPCL & & & -2.388 & -3.657 & 2.939 \\
\hline & & & $(0.075)$ & $(0.022)$ & $(0.042)$ \\
\hline BPCL & & & & -0.548 & 4.29 \\
\hline GAIL & & & & $(0.613)$ & $(0.013)$ \\
\hline & & & & & \\
\hline
\end{tabular}

Source: - Secondary Data Analysis

In Table 6, the mean value of variable of ONGC is not significant from IOCL, HPCL, BPCL and GAIL. It indicates that there is no significant different in mean of ONGC from others. The mean value of IOCL is greater than the critical value of 0.042 with GAIL. Same as in case of HPCL and GAIL and BPCL and GAIL. Hence there is a significant difference in DPS in selected companies. Hence the null hypothesis is rejected.
Table 7: DPR Paired Samples Test

\begin{tabular}{|l|l|l|l|l|l|}
\hline COMPANY & ONGC & IOCL & HPCL & BPCL & GAIL \\
\hline ONGC & & -0.277 & 1.563 & -0.489 & 2.143 \\
\cline { 2 - 6 } & & $(0.796)$ & $(0.193)$ & $(0.651)$ & $(0.099)$ \\
\hline IOCL & & & 1.041 & -0.251 & 1.779 \\
\hline HPCL & & & $(0.351)$ & $(0.814)$ & $(0.150)$ \\
\hline BPCL & & & & -1.584 & 0.697 \\
& & & & $(0.188)$ & $(0.524)$ \\
\hline GAIL & & & & & 1.829 \\
& & & & & $(0.141)$ \\
\hline
\end{tabular}

Table 7 depicts the mean value between ONGC vs. IOCL, ONGC vs. HPCL, ONGC vs. BPCL and ONGC vs. GAIL. IT has been found that there is no significant difference between ONGC and IOCL, ONGC and BPCL. The mean value of DPR of ONGC and HPCL and GAIL is significantly different. Same as the mean value of DPR of IOCL with HPCL and GAIL and HPCL and GAIL are significantly different.

\section{CONCLUSION}

This research paper describes the pattern of dividend policy and earnings. Researchers have done technical analysis of DPS, EPS and DPR patterns on selected 5 stocks during the study period. The study gives the peer comparison among selected companies from the oil and power sector regarding the dividend pattern and earnings. It is concluded that overall findings and discussion that total highest EPS was paid by HPCL and total DPS was paid by BPCL. Like DPS, BPCL also paid high dividend pay-out in five years however the result of ANOVA indicated that there is no difference in pay-out ratio. ONGC paid the lowest EPS as compared to BPCL and HPCL but it paid a stable dividend per share which shows that it does not follow its earnings. We can say that the companies from the same industry do not follow the same pattern in dividend and earnings. EPS and DPS growth have been seen similar in HPCL and BPCL. It is a good indicator as the company's profit will increase in future so DPR will also increase. These both are good dividend stocks for investors to yield good dividend income in the short term however dividend yield is not only a single factor for investment decision. Sometimes a stock which yields a good dividend today may not yield a good or negative return in the following years. It is important to look at dividend yield for analysis of financial performance but in conjunction with other variables like sales, Profit, $\mathrm{P} / \mathrm{E}$ ratio, market price should also be considered. 


\section{REFERENCES}

[1] Al-Ajmi, J. H. (2011). Corporate Dividends Decisions: Evidence from Saudi Arabia. The Journal of Risk Finance, 12(1), 41-56.

[2] Balakrishnan, D. K. (2016). A Study on Impact of Earnings per Share, Dividend per Share, Price earning Ratio on Behaviour of Share Market Prices Movements (Pharma Sector) with special reference to NSE. International Journal of Advance Research and Innovative Ideas in Education, 2(1), 381-390.

[3] Dr. Nandan Velankar, A. C. (2017). Impact of EPS and DPS on Stock Price: A Study of Selected Public Sector Banks in India. Prestige International Journal of Management \& IT Sanchayan, 6(1), 111-121.

[4] F., M. M. (1961). Dividend Policy, Growth and the Valuation of Shares. The Journal of Business, 34(4), 411-433.

[5] Joshua Aroni, P. G. (2014). Influence of Dividend payout on Investment in Shares: A Survey of Retail Investors in Kenya. International Journal of Business \& Social Science, 5(1), 155-163.

16] Kumar, D. J. (2019). Behaviour Pattern of Dividend Payout: A Study in Selected Bluechip Companies in india. Indian Journal of Accounting, 51(2), 6772 .

[7] M., G. (1959). Dividends, Earnings \& Stock Prices. Review of Economics \& Statistics, 41, 99-105.

[8] P., W. (1970). How to Calculate Savings Possible Through Reduction of Working Capital. Financial Executive, 50-58.

[9] Pandithratna, H. K. (2017). The Effect of Dividend Policy on Corporate Profitability: An Empirical Study on Bevarage, Food \& Tobacco Industry in Sri Lanka. International Journal of Scientific and Research Publications, 7(8), 542-546.

[10] Rastogi, G. P. (2019). Sectoral Analysis of factors Influencing Dividend Policy: Case of an Emerging Financial Marlet. Journal of Risk \& Financial Management, 12(110), 1-18. 